\title{
Expression of the CTCF gene in bovine oocytes and preimplantation embryos
}

\author{
Álvaro F.L. Rios ${ }^{1}$, Daniela C. Lemos ${ }^{1}$, Maurício B. Fernandes ${ }^{1}$, Maria V. Andrea ${ }^{1}$, Marcus V.M. Gomes ${ }^{1}$, \\ Raysildo B. Lôbo ${ }^{1}$, Mendelson Mazucato ${ }^{1}$ and Ester S. Ramos ${ }^{1,2}$ \\ ${ }^{1}$ Departamento de Genética, Faculdade de Medicina de Ribeirão Preto, Universidade de São Paulo, \\ São Paulo, SP, Brazil. \\ ${ }^{2}$ Departamento de Ginecologia e Obstetrícia, Faculdade de Medicina de Ribeirão Preto, \\ Universidade de São Paulo, Ribeirão Preto, SP, Brazil.
}

\begin{abstract}
The CCCTC - binding factor (CTCF) is a protein involved in repression, activation, hormone-inducible gene silencing, functional reading of imprinted genes and X-chromosome inactivation. We analyzed CTCF gene expression in bovine peripheral blood, oocytes and in different cellular stages (2-4 cells, 8-16 cells, 16-32 cells, morulae, and blastocysts) of in vitro fertilized embryos. This is the first report of CTCF expression in oocytes and preimplantation bovine embryos and has implications for the production of embryonic stem cells and the development of novel medical technologies for humans.
\end{abstract}

Key words: CTCF, genomic imprinting, preimplantation embryos, X-inactivation.

Received: October 20, 2006; Accepted: May 10, 2007.

The zinc finger protein CCCTC-binding factor (CTCF) was initially described as a "multivalent" nuclear factor, capable of specific recognition of varying DNA sites through its 11-zinc fingers (ZFs) (Ohlsson et al., 2001). Although it is described as a ubiquitously expressed factor, Loukinov et al. (2002) showed loss of CTCF expression in a select population of male germinative cells. The CTCF protein is involved with repression, activation and hormone-inducible gene silencing, creating constitutive chromatin insulators or boundaries and the functional reading of the imprinted genes (Rasko et al., 2001; Klenova et al., 2002).

Usually, CTCF targets show rich $\mathrm{CpG}$ content as evidenced in the $M Y C$ gene and in the imprinting control region (ICR) between the IGF2 and $H 19$ genes (Holmgren et $a l ., 2001)$. In addition, the CTCF has been reported to interact with the ICRs mapped in the region coding for human Prader-Willi/Angelman syndromes and a differentially methylated region (DMR) within the domain of reciprocally imprinted Dlk and Gtl2 genes (Klenova et al., 2002). It was also observed that many types of cancers (including colorectal cancer, Wilms' tumor and bladder tumors) show abnormal methylation of CTCF targets or mutations within the ZF domain of the gene (Cui et al., 2001; Nakagawa et

Send correspondence to Álvaro Fabrício Lopes Rios. Departamento de Genética, Faculdade de Medicina de Ribeirão Preto, Universidade de São Paulo, Av Bandeirantes 3900, 14049-900 Ribeirão Preto, SP, Brazil. E-mail: afrios@genbov.fmrp.usp.br. al., 2001; Filippova et al., 2002; Klenova et al., 2002). Many tandem CTCF-binding sites also affect the methylation-dependent silencing of the $\mathrm{X}$ chromosome (Chao et al., 2002).

Components governing cell growth, differentiation and death may be influenced by CTCF. Some authors (Rasko et al., 2001; Klenova et al., 2002) have reported that concurrent effects of CTCF on multiple genes (including p19/ARF, p16/INK4a, PIM-1, PLK, BRCA1, TP53, p27, $E 2 F 1, T E R T$, and $I G F 2$ ) synergize with reduced expression of $M Y C$ to induce cell cycle arrest at multiple stages of the cycle. Epimutations in DMRs overlapping CTCF-binding sites have been showed in mouse preimplantation embryos cultured in different mediums (Doherty et al., 2000; Khosla et al., 2001). Increased methylation of H19DMR and decreased developmental competence of CTCF-deficient oocytes has been reported in mouse with reduced amounts of CTCF protein (Fedoriw et al. 2004). However, although the CTCF protein can be involved in the establishment of normal and abnormal epigenotypes in murines the functions of this protein and its expression pattern are as yet unknown in bovine embryos and oocytes.

For our study, bovine $C T C F$ gene primer sequences were obtained and designed by the comparative analysis of identity among human and various mammalian and bird species using the basic local alignment search tool (BLAST) and the Gene Runner program v.3.05 (www. generunner.com). We collected peripheral blood from 10 
adult animals (bulls and dams) and oocytes from the ovaries of adult dams humanely slaughtered at an abattoir in Sertãozinho in the Brazilian state of São Paulo.

Embryos were produced by in vitro fertilization (Meirelles et al., 2001) and pools of 50 embryos from each stage of the preimplantation period were maintained in $10 \mu \mathrm{L}$ of RNAlater (Ambion, USA) at $-80{ }^{\circ} \mathrm{C}$ until required. Total RNA was isolated from pools of 50 embryos and from 50 oocytes using the RNeasy Mini Kit (Qiagen, USA) and from peripheral blood with Trizol (Invitrogen, Brazil), following the manufacturer's instructions in both cases. All RNA samples were digested with $1 \mathrm{U}$ of Dnase I (Invitrogen, Brazil) to avoid contamination with genomic DNA and the assays were repeated at least three times. The total RNA was reverse-transcribed into cDNA according to the protocol provided with the SUPERSCRIPTII RNase H'Reverse Transcriptase kit (Invitrogen, USA), the CTCF primer pairs (Invitrogen, Brazil) being 5'-ACTTACCAGA GACGCCGGGA-3' (forward) and 5'-GCTGGTGGCTG ATAGTCTGG-3' (reverse). To exclude a possible amplification of a gene with a very similar sequence, the PCR products of the CTCF cDNA (533 bp) correspond to a non-overlapping region with the paralogue gene BORIS. Each reverse-transcribed cDNA from blood, oocyte or embryo was first amplified by PCR with the $\beta$-actin primer pairs (Invitrogen, Brazil) 5'-CCGTCTTCCCGTCCATCG TG-3' (forward) and 5'- GGATGCCTCTCTTGCTCTG A-3' (reverse) (cDNA $=108 \mathrm{bp})$ to ensure the absence of contaminating genomic DNA. The PCR reactions were performed in a Biometra TGradient (Biometra, UK) in a final volume of $25 \mu \mathrm{L}$ containing $3 \mu \mathrm{L}$ of each cDNA sample, $10 \mathrm{mM}$ Tris- $\mathrm{HCl}, 1.5 \mathrm{mM} \mathrm{MgCl} 2,100 \mu \mathrm{M}$ of each dNTP, $0.05 \mathrm{mM}$ of each primer and 1 unit of Taq DNA polymerase (Gibco BRL, USA). Thermal cycle conditions for both the CTCF and $\beta$-actin primers consisted of initial denaturation at $94{ }^{\circ} \mathrm{C}$ for $3 \mathrm{~min}$, followed by 35 cycles at $94{ }^{\circ} \mathrm{C}$ for $1 \mathrm{~min}, 64^{\circ} \mathrm{C}$ for $2 \mathrm{~min}$ and $72^{\circ} \mathrm{C}$ for $2 \mathrm{~min}$, with a final extension at $72{ }^{\circ} \mathrm{C}$ for $10 \mathrm{~min}$. The PCR products were separated on $10 \%(\mathrm{w} / \mathrm{v})$ polyacrylamide gel and silverstained and individual bands were directly sequenced using the BigDye (Applied Biosytems, USA). The final sequence was submitted to GenBank under accession number AY205566.

The isolated $C T C F$ sequence showed $93 \%$ of identity with its human counterpart. We observed $C T C F$ gene expression in all the bovine samples analyzed, i.e. peripheral blood, oocytes and embryos at different cellular stages (2-4 cells, 8-16 cells, 16-32 cells, morulae, and blastocysts) (Figure 1A). The absence of DNA contamination was demonstrated by the amplification of the $\beta$-actin control and the absence of the intronic sequence (Figure 1B). Despite numerous advances in the field of in vitro fertilization, implantation rates per embryo transferred are still low for bovines. This may reflect epigenetic disruptions in chro-

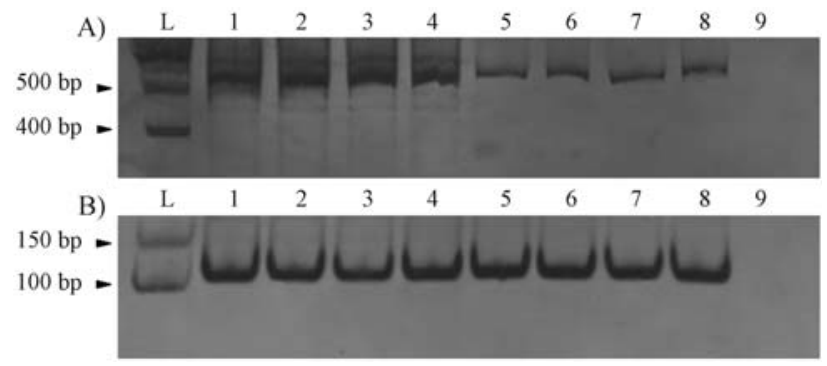

Figure 1 - A) Detection of $C T C F$ transcripts: (1) immature oocytes, (2) mature oocytes, (3) 2 to 4 stage embryos, (4) 8 to 16 stage embryos, (5) 16 to 32 stage embryos, (6) morulae, (7) blastocysts and (7) blood. (L) Molecular marker, (9) Negative control. B) Detection of $\beta$-actin transcripts: same as 1 to 8 above.

matin structures, such as the abnormal methylation patterns observed in cloned bovine embryos and alteration of the expression of multiple developmental genes such as $I G F 2$ and $H 19$ (Dean et al., 2001; Khosla et al., 2001). To improve assisted reproductive techniques there is still a great need to elucidate the specific mechanisms which control the development of early mammalian embryos.

Because of the ethical issues involved with medical research involving human embryos, a good animal model is needed. There is mounting evidence that the bovine model is better than the murine model for the study of human embryonic development in respect to the timing of genome activation, intermediate metabolism and interaction with the culture medium (Wrenzycki et al., 2001). However, molecular markers associated with epimutations are poorly characterized in cattle compared with mice and humans and, therefore, it is important to delineate the effective role of these genes and their expression patterns in bovine. Although $C T C F$ expression has been considered to be ubiquitous cells have been detected in mouse male gonads that do not express this gene during a period that has been associated with the establishment of the imprinting marks (Loukinov et al. 2002).

Our observations reflect the CTCF transcriptional activity in preimplantation embryos and indicate the importance of such activity at this stage of mammalian development. Disruption of CTCF expression might influence the regulation of developmental genes, especially since the critical role of CTCF in the epigenetic regulation of higher order chromatin and gene silencing has been demonstrated (Schoenherr et al. 2003). Some candidate genes for a primary role in the development of the large offspring syndrome (LOS) phenotype in ruminants conceived by in vitro fertilization are regulated by CTCF (Bell et al., 2000; Fitzpatrick et al., 2007). Furthermore, CTCF down-regulation could cause loss of imprinting due to decreased rates of CTCF binding to the H19DMR (Fu et al., 2004). This epimutation pattern is similar to those produced by approaches involving RNAi (Fedoriw et al., 2004).

The causes of CTCF down-regulation in cell culture are as yet unknown, but the presence of fetal serum in 
embryo culture mediums has been demonstrated to affect several other genes expressed during mammalian embryo development (Rizos et al., 2003). Other evidence supporting $\mathrm{CTCF}$ involvement in epimutations is the presence of a serine-protease in fetal calf serum that cleaves CTCF protein at three sites and can result in post-translational downregulation (Vostrov and Quitschke, 2000). Based on CTCF down-regulation, RNAi experiments and our results, the CTCF protein could be proposed as a candidate factor involved in the epimutations described in embryos cultured in vitro (Doherty et al., 2000; Khosla et al., 2001). Based on such evidence, we propose that a revaluation of the gene expression patterns in animals affected with LOS should focus on the CTCF gene and CTCF-regulated genes.

If there is the possibility that CTCF participates in the establishment of normal and abnormal epigenotypes during embryonic development, we could hypothesize a similar involvement in the development of embryonic stem cells. This should be investigated in detail because the production of embryonic stem cells is important for the development of novel medical technologies. To our knowledge, this is the first report showing $C T C F$ transcripts in bovine preimplantation embryos and the presence of this gene in cattle. Our results indicate that the $C T C F$ gene was not repressed during oocyte maturation during the period associated with the establishment of female imprinting in bovines, in contrast to the situation in mouse male germ cells as reported by Loukinov et al. (2002). This difference in gene expression pattern between male and female germ cells could be associated with the differential methylation marks on imprinted loci. However, future studies, including environment influences and the subsequent analysis of expression patterns during different stages of development are needed to identify the complete role and real importance of the CTCF gene.

\section{Acknowledgments}

We thank Dr. Andrew Watson and Dr. Allan W. King for their assistance and encouragement. This work was supported by the Brazilian agencies CAPES, CNPq (Processes 408856/2006-8 / 141548-2003-7), FAEPA, PRONEX and FAPESP (Process 2005/00616-5).

\section{References}

Bell AC and Felsenfeld G (2000) Methylation of CTCF-dependent boundary controls imprinted expression of the $\operatorname{Igf} 2$ gene. Nature 405:482-485.

Chao W, Huynh KD, Spencer RJ, Davidow LS and Lee JT (2002) $\mathrm{CTCF}$, a candidate trans-acting factor for X-inactivation choice. Science 295:345-347.

Cui H, Niemitz EL, Ravenel JD, Onyango P, Brandenburg SA, Lobanenkov VV and Feinberg AP (2001) Loss of imprinting of insulin-like growth factor-II in Wilms' tumor commonly involves altered methylation but not mutations of CTCF or its binding site. Cancer Res 61:4947-4950.
Dean W, Santos F, Stojkovic M, Zakhartchenko V, Walter J, Wolf E and Reik W (2001) Conservation of methylation reprogramming in mammalian development: Aberrant reprogramming in cloned embryos. Proc Natl Acad Sci USA 98:13734-38.

Doherty AS, Mann MRW, Tremblay KD, Bartolomei MS and Schultz RM (2000) Differential effects of culture on imprinted H19 expression in the preimplantation mouse embryo. Biol Reprod 62:1526-1535.

Fedoriw AM, Stein P, Svoboda P, Schultz RM and Bartolomei MS (2004) Transgenic RNAi reveals essential function for CTCF in H19 gene imprinting. Science 303:238-240.

Filippova GN, Qi CF, Ulmer JE, Moore JM, Ward MD, Hu YJ, Loukinov DI, Pugacheva EM, Klenova EM, Grundy PE, et al. (2002) Tumor-associated zinc finger mutations in the CTCF transcription factor selectively alter its DNA-binding specificity. Cancer Res 62:48-52.

Fitzpatrick GV, Pugacheva EM, Shin J, Abdullaev, Yang Y, Khatod K, Lobanenkov VV and Higgins MJ (2007) Allele-specific binding of CTCF to the multipartite imprinting control region KvDMR1. Mol Cell Biol 27:2636-2647.

Fu VX, Schwarze SR, Kenowski ML, Leblanc S, Svaren J and Jarrard DF (2004) A loss of insulin-like growth factor-2 imprinting is modulated by CCCTC-binding factor downregulation at senescence in human epithelial cells. J Biol Chem 10:52218-52226.

Holmgren C, Kanduri C, Dell G, Ward A, Mukhopadhya R, Kanduri M, Lobanenkov VV and Ohlsson R (2001) CpG methylation regulates the Igf2/H19 insulator. Curr Biol 11:1128-1130.

Khosla S, Dean W, Brown D, Reik W and Feil R (2001) Culture of pleimplantaion mouse embryos affects fetal development and expression of imprinted genes. Biol Reprod 64:918-926.

Klenova EM, Morse III HC, Ohlsson R and Lobanenkov VV (2002) The BORIS+CTCF gene family is uniquely involved in the epigenetics of normal biology and cancer. Semin Cancer Biol 12:399-414.

Loukinov DI, Pugacheva E, Vatolin S, Pack SD, Moon H, Chernukhin I, Mannan P, Larsson E, Kanduri C, Vostrov AA, et al. (2002) BORIS, a novel male germ-line-specific protein associated with epigenetic reprogramming events, shares the same 11-zinc-finger domain with CTCF, the insulator protein involved in reading imprinting marks in the soma. Proc Natl Acad Sci USA 99:6806-6811.

Meirelles FV, Bordignon V, Watanabe Y, Watanabe M, Dayan A, Lobo RB, Garcia JM and Smith LC (2001) Complete replacement of the mitochondrial genotype in a Bos indicus calf reconstructed by nuclear transfer to a Bos taurus oocyte. Genetics 158:351-356.

Nakagawa H, Chadwick RB, Peltomaki P, Plass C, Nakamura Y and de La Chapelle A (2001) Loss of imprinting of the growth factor II gene occurs by biallelic methylation in a core region of H19-associated CTCF-biding sites in colorectal cancer. Proc Natl Acad Sci USA 98:591-596.

Ohlsson R, Renkawitz R and Lobanenkov VV (2001) CTCF is a uniquely versatile transcription regulator linked to epigenetics and disease. Trends Genet 17:520-527.

Rasko JE, Klenova EM, Leon J, Filippova GN, Loukinov DI, Vatolin $\mathrm{S}$, Robinson $\mathrm{AF}, \mathrm{Hu} \mathrm{YJ}$, Ulmer J, Ward MD, et al. (2001) Cell growth inhibition by the multifuncional multivalent zinc-finger factor CTCF. Cancer Res 61:6002-6007. 
Rizos D, Gutiérrez-Adán A, Pérez-Garnelo S, de la Fuente J, Boland MP and Lonergan P (2003) Bovine embryo culture in the presence or absence of serum: Implications for blastocyst development, cryotolerance, and messenger mRNA expression. Biol Reprod 68:236-243.

Schoenherr CJ, Levorse JM and Tilghman SM (2003) CTCF maintains differential methylation at the Igf2/H19 locus. Nat Genet 33:66-69.

Vostrov AA and Quitschke WW (2000) Plasma hyaluronan-binding protein is a serine protease. J Biol Chem 28:2297822985.
Wrenzycki C, Herrmann D, Keskintepe L, Martins A Jr, Sirisathien S, Brackett B and Niemann H (2001) Effects of culture system and protein supplementation on mRNA expression in pre-implantation bovine embryos. Human Reprod 16:893-901.

\section{Internet Resources}

BLAST: http://www.ncbi.nlm.nih.gov/BLAST.

Gene Runner: http://www.generunner.com. Associate Editor: Ricardo Guelerman P. Ramos 